University of Nebraska - Lincoln

DigitalCommons@University of Nebraska - Lincoln

Mammalogy Papers: University of Nebraska

State Museum

Museum, University of Nebraska State

2010

New Records of Bats from the British Virgin Islands

\author{
Gary G. Kwiecinski \\ University of Scranton, ggk301@scranton.edu \\ Jean-Pierre Bacle \\ Island Resources Foundation, Washington DC, dcbacle@aol.com \\ Kevel C. Lindsay \\ Island Resources Foundation, Washington DC, klindsay@irf.org \\ Hugh H. Genoways \\ University of Nebraska - Lincoln, h.h.genoways@gmail.com
}

Follow this and additional works at: https://digitalcommons.unl.edu/museummammalogy

Part of the Zoology Commons

Kwiecinski, Gary G.; Bacle, Jean-Pierre; Lindsay, Kevel C.; and Genoways, Hugh H., "New Records of Bats from the British Virgin Islands" (2010). Mammalogy Papers: University of Nebraska State Museum. 140. https://digitalcommons.unl.edu/museummammalogy/140

This Article is brought to you for free and open access by the Museum, University of Nebraska State at DigitalCommons@University of Nebraska - Lincoln. It has been accepted for inclusion in Mammalogy Papers: University of Nebraska State Museum by an authorized administrator of DigitalCommons@University of Nebraska Lincoln. 


\title{
New records of bats from the British Virgin Islands
}

\author{
Gary G. Kwiecinski ${ }^{1}$, Jean-Pierre Bacle ${ }^{2}$, Kevel C. Lindsay ${ }^{2}$, and Hugh H. Genoways ${ }^{3}$ \\ ${ }^{1}$ Biology Department, University of Scranton, Scranton, PA 18510-4625, USA; \\ ${ }^{2}$ Island Resources Foundation, 1718 P Street, N.W., \#T4, Washington, DC 20036, USA; \\ ${ }^{3}$ University of Nebraska State Museum, W436 Nebraska Hall, Lincoln, NE 68588-0514, USA. \\ Corresponding author: ggk301@scranton.edu
}

\begin{abstract}
Aвstract.-As currently understood the bat fauna of the British Virgin Islands consists of five species Noctilio leporinus, Brachyphylla cavernarum, Artibeus jamaicensis, Tadarida brasiliensis, and Molossus molossus. Our knowledge of distribution of bats in the British Virgin Islands is far more limited than that in the United States Virgin Islands. As part of ongoing research on the bats of the Virgin Islands, recent brief surveying periods in the British Virgin Islands have produced new records for some islands. Also, our researching of existing museum collections has discovered unreported new records. Our new data adds information for five species of bats from five islands in the British Virgin Islands-Guana, Jost Van Dyke, Mosquito, Norman, and Tortola.
\end{abstract}

KEYWORDS.-Chiroptera, biodiversity, Virgin Islands, conservation, distribution

\section{INTRODUCTION}

The study of the distribution and taxonomy of the chiropteran fauna of the Virgin Islands has a long history, with considerable work being done in the last 50 years (J. A. Allen, 1890; G. M. Allen, 1911; Bond and Seaman, 1958; Davis, 1973; Goodwin, 1928; Hall and Bee, 1960; Hall and Tamsitt, 1968; Koopman, 1975; Kwiecinski and Coles, 2007; La Bastille and Richmond, 1973; Lazell and Jarecki, 1985; Starrett, 1962; Swanepoel and Genoways, 1978). As currently understood the bat fauna of the Virgin Islands is composed of 6 species-Noctilio leporinus, Brachyphylla cavernarum, Artibeus jamaicensis, Stenoderma rufum, Tadarida brasiliensis, and Molossus molossus. However, all six of these species are known to occur on only a single island-St. John in the United States (U.S.) Virgin Islands-and five of these species are known from only St. Thomas and St. Croix, both in the U. S. Virgin Islands, where Tadarida brasiliensis has not been reported. However, our knowledge of distribution of bats in the British Virgin Islands is far more limited than that in the U. S. Virgin Islands.

As part of ongoing research on bats of the U. S. Virgin Islands (Bacle et al. 2008), Bacle and Lindsay have undertaken three brief collecting periods in the British Virgin Islands in 2007 and 2008 that greatly expand our knowledge of this chiropteran fauna. In addition, our researching of existing museum collections has discovered unreported new records of three species of bats from three islands in the British Virgin Islands that significantly increase our knowledge of the distribution of these species. Our new data adds information for five species of bats from five islands in the British Virgin Islands-Guana, Jost Van Dyke, Mosquito, Norman, and Tortola. We report these new records herein to establish, in part, a database comparable to other Antillean islands that could be applicable to conservation, management, and other biodiversity maintenance efforts.

\section{Methods AND Materials}

\section{Study area}

The British Virgin Islands are a collection of more than 40 islands, islets, and rocky outcroppings filling the eastern-most portion of the area between Puerto Rico and the northern Lesser Antilles (Fig. 1). All of these islands, except Anegada, are mountainous 


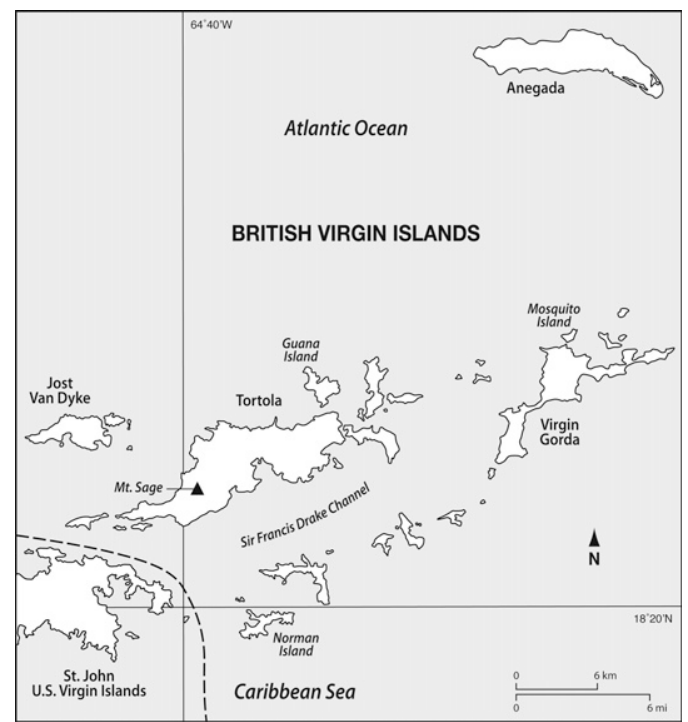

FIG. 1. Map of the British Virgin Islands and a portion of the United States Virgin Islands. The dashed line represents the political boundary between the two.

and of volcanic origin. Anegada is composed of coral and limestone. Guana, Mosquito, and Norman islands are small, privately owned, and, except for a few resorts, have no permanent residents. Conservation efforts have preserved much of the native flora and fauna on these small islands. Tortola is the largest and most heavily populated of the British Virgin Islands and is capped by Mt. Sage at $530 \mathrm{~m}$, the highest point in the island group. Jost Van Dyke is the fourth largest island in the group, has an elevation of $321 \mathrm{~m}$, and was highly involved in agricultural endeavors until the 1960s.

\section{Survey techniques}

Bats were surveyed in the British Virgin Islands in two ways during three field periods in 2007 and 2008. Mist-netting surveys consisted of four nights of observation and collecting efforts during two periods, 1-5 July and 14 October 2008. Mist-netting for bats was conducted in a variety of habitats, including naturally vegetated ghuts, small fruit plantations, and access roads. Two or three mist-nets were erected at 20 to $50 \mathrm{~m}$ intervals at each location and monitored for four to six hours depending on activity and weather. After being removed from nets, captured bats were held in cloth bags until the nets were dismantled at the end of the evening. Bats were examined at the end of the evening, with some selected as voucher specimens and the remaining individuals released. The other survey method was used on 19 June 2007 when day roosts were searched for the presence of bats. Selected individuals from this search were preserved as voucher specimens.

\section{Voucher specimens}

Specimens collected during field work in 2007 and 2008 have been deposited in the collections of the Museum of Texas Tech University (TTU). We also examined earlier material housed in this collection. Other collections from which specimens were examined include the American Museum of Natural History (AMNH); Field Museum of Natural History (FMNH); University of Nebraska State Museum (UNSM). Length of forearm and cranial measurements were taken from museum specimens using digital calipers. Measurements are given in millimeters and weights are in grams.

\section{REsUlts}

\section{Species Accounts}

Noctilio leporinus mastious (Vahl, 1797)

Specimens examined (6).--Norman Island: sea caves, Treasure Point, 5 (1 FMNH, 4 UNSM). Guana Island, 1 (AMNH).

These specimens are the first documentation of the greater fishing bat from Norman Island and Guana Island. The specimens from Norman Island were taken at the same location by two collectors on two different dates-on 10 July 1976 Ronald H. Pine captured a single adult male and on 3 June 1979 three males and one female were netted by Michael Ivie. The latter specimens were taken in a net set about a meter above the water level across the entrance of a sea cave. The specimen from Guana Island was an adult female obtained by R. Rusher and J. Walsh on 15 July 1988. This specimen was cited by museum number (AMNH 256528) by Lazell (2005), but measurement data were not presented. 


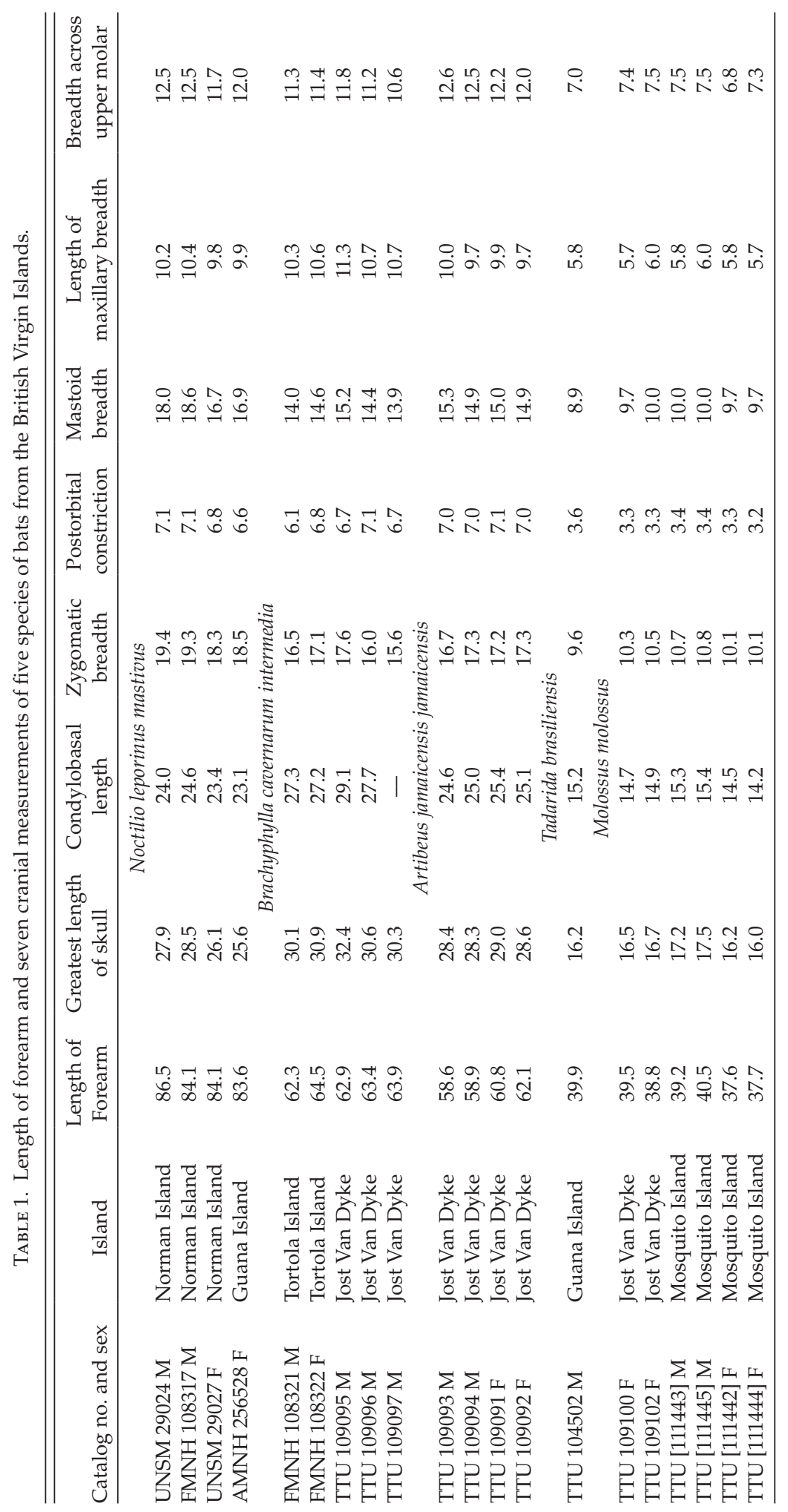


Length of forearm and seven cranial measurements for two males and the female from Norman Island and the female from Guana Island are presented in Table 1. These measurements match closely those of the West Indian sample studied by Davis (1973); therefore, we assign these specimens to N. l. mastious based on the analyses of Davis (1973), who applied this taxon to all Caribbean and circum-Caribbean populations.

Testes lengths of the males from Norman Island were $8,9.5,7.5$, and 6, respectively, and the female was carrying a single embryo that measured 29 in crown-rump length. The female from Guana Island evinced no gross reproductive activity (Lazell, 2005: 201).

\section{Brachyphylla cavernarum intermedia} Swanepoel and Genoways, 1978

Specimens examined (6).- Tortola Island: Mt. Sage, ca. 530 m, 2 (FMNH). Jost Van Dyke: Great Harbour [18 $26^{\prime} 43.9^{\prime \prime} \mathrm{N}, 64^{\circ} 44^{\prime}$ 52.4"W], 9 m, 4 (TTU).

These are the first representatives of the Antillean cave bat known from Tortola and Jost Van Dyke. This bat is primarily cave roosting, but has been found roosting in human structures and trees (Swanepoel and Genoways, 1983). Its presence indicates suitable roosting habitat must be available on both islands. The male and female specimens from Tortola were taken on 23 and 24 July 1976 by Ronald H. Pine. The four males from Jost Van Dyke were taken on the night of 1 July 2008 in Great Harbour along with four A. jamaicensis by Jean-Pierre Bacle and Kevel Lindsay. These bats were taken on the east side of the Great Harbour community using three mist nets, two mist nets placed in association with bananas and mangos and one placed across a road.

Length of forearm and seven cranial measurements of two specimens from Tortola and three from Jost Van Dyke are presented in Table 1 . Two subspecies of $B$. cavernarum were recognized by Swanepoel and Genoways (1978) in the Virgin IslandsB. c. cavernarum confined to St. Croix and B. $c$. intermedia on the remainder of the islands in the group. The measurements of the specimens from Tortola match the smaller size of individuals in samples from St. John, St. Thomas, and Norman Island rather than the larger individuals in the sample from St. Croix (Swanepoel and Genoways, 1978: 38). In fact, the measurements of the specimens from Tortola, fall at or below the mean of the samples for St. John, St. Thomas, and Norman Island in half of these measurements-greatest length of skull, condylobasal length, zygomatic breadth, and length of maxillary toothrow. The three males measured from Jost Van Dyke present an interesting case, with two individuals falling within or below the range of measurements for B. c. intermedia; however, the measurements of the other specimen TTU 109095 fall within the range of the larger B. c. cavernarum. Despite this one individual it appears that the subspecies of B. c. intermedia occupies the islands of the British Virgin Islands, and unlike the claim of Lazell (2005), the differences between these two subspecies are not weak, but actually quite distinct, especially in such measurements as greatest length of skull, length of maxillary toothrow, and breadth across the upper molars (Swanepoel and Genoways, 1978: 38).

The testes length of the adult male from Tortola was 6.5 and the adult female revealed no gross reproductive activity. Testes lengths for the males from Jost Van Dyke were 3, 3, 3.5, and 4.5. The weights of the males from Jost Van Dyke were 34, 38, 44, and 47.

\section{Artibeus jamaicensis jamaicensis Leach, 1821}

Specimens examined (6).--Jost Van Dyke: Great Harbour [ $18^{\circ} 26^{\prime} 43.9^{\prime \prime} \mathrm{N}, 64^{\circ} 44^{\prime} 52.4^{\prime \prime} \mathrm{W}$ ], 9 m, 4 (TTU); Ridge Road [18 $27^{\prime} 05.6^{\prime \prime} \mathrm{N}$, 644ㄴ $\left.49.1^{\prime \prime} \mathrm{W}\right], 233 \mathrm{~m}, 1$ (TTU); White Bay [18 $\left.26^{\prime} 38.6^{\prime \prime} \mathrm{N}, 64^{\circ} 45^{\prime} 53.6^{\prime \prime} \mathrm{W}\right], 3 \mathrm{~m}, 1$ (TTU).

These six specimens captured by JeanPierre Bacle and Kevel Lindsay are the first record of the Jamaican fruit bat from the island of Jost Van Dyke. On the night of 3 July 2008, one net was placed across Ridge Road, but did not catch any bats, whereas one placed nearby, across a side road under a mango tree caught one $A$. jamaicensis and one M. molossus. On 5 July in White Bay, two nets were placed in the vicinity of a small grove of bananas and caught three Jamaican 
fruit bats. Conditions on 1 July when twelve A. jamaicensis were taken in Great Harbour are described in the account for B. cavernarum. Table 1 presents length of forearm and seven cranial measurements for two males and two females from Jost Van Dyke. The values for these bats fit well within the range of measurements for populations of the nominate subspecies as presented by Genoways et al. (2001).

Two females taken on 1 July were pregnant with single fetuses that measured 38 and 40 in crown-rump length and one taken on 3 July carried a fetus measuring 42 in crown-rump length. Two males obtained on 1 July and one taken on 5 July had testes that measured 4, 9, and 10 in length, respectively. Three males weighed 35, 38, and 45 . In four specimens examined, all were missing both third upper molars and all had both lower third molars.

\section{Tadarida brasiliensis antillularum (Miller, 1902)}

Specimen examined (1).-Guana Island, 1 (TTU).

Michelle Theberge took a male Brazilian free-tailed bat on 16 October 2004 on Guana Island, which was mentioned in a sidebar by Lazell (2005: 205). Brazilian free-tailed bats primarily find day roosts in caves and rock crevices, but it has been taken in association with human structures on a few Antillean islands (Anthony, 1925; Taboada, 1979). This is only the second island in the Virgin Islands, along with St. John, U.S.V.I. (Hall and Bee, 1960), from which this species has been recorded (Table 2). The length of testes of this individual was 4 and it weighed 11. Length of forearm and cranial measurements of this male are presented in Table 1 . The subspecific name T. $b$. antillularum has been applied to populations from Puerto Rico through the Lesser Antilles (Koopman, 1975).

\section{Molossus molossus fortis Miller, 1913}

Specimens examined (6).--Mosquito Island: Hay Point [18 $\left.30^{\prime} 38.7^{\prime \prime} \mathrm{N}, 64^{\circ} 24^{\prime} 02.2^{\prime \prime} \mathrm{W}\right]$, 45 m, 4 (TTU). Jost Van Dyke: Ridge Road [18 $\left.27^{\prime} 05.6^{\prime \prime} \mathrm{N}, \quad 64^{\circ} 44^{\prime} 49.1^{\prime \prime} \mathrm{W}\right], 233 \mathrm{~m}$, 1 (TTU); East End Harbour, Brown Ghut [18 $\left.26^{\prime} 52.4^{\prime \prime} \mathrm{N}, 64^{\circ} 43^{\prime} 47.2^{\prime \prime} \mathrm{W}\right], 8 \mathrm{~m}, 1$ (TTU).

The specimens of Molossus from Mosquito Island are the first bats of any species to be reported from the island and the two individuals from Jost Van Dyke are the first

TAвLe 2. - Distribution of bats in the Virgin Islands (updated from Lazell and Jarecki, 1985). Based on data from Koopman (1975), Lazell and Jarecki (1985), Kwiecinski and Coles (2007), and current paper.

\begin{tabular}{|c|c|c|c|c|c|c|c|c|c|}
\hline Island & $\begin{array}{l}\text { Area in } \\
\text { hectares }\end{array}$ & $\begin{array}{l}\text { Elevation } \\
\text { in meters }\end{array}$ & $\begin{array}{l}\text { Noctilio } \\
\text { leporinus }\end{array}$ & $\begin{array}{c}\text { Brachyphylla } \\
\text { cavernarum }\end{array}$ & $\begin{array}{c}\text { Artibeus } \\
\text { jamaicensis }\end{array}$ & $\begin{array}{c}\text { Stenoderma } \\
\text { rufum }\end{array}$ & $\begin{array}{c}\text { Tadarida } \\
\text { brasiliensis }\end{array}$ & $\begin{array}{l}\text { Molossus } \\
\text { molossus }\end{array}$ & $\begin{array}{c}\text { Total } \\
\text { species } \\
\text { present }\end{array}$ \\
\hline \multicolumn{10}{|c|}{ BRITISH VIRGIN ISLANDS } \\
\hline Anegada & 3,872 & 9 & - & - & + & - & - & - & 1 \\
\hline Guana & 297 & 266 & + & + & + & - & + & + & 5 \\
\hline $\begin{array}{c}\text { Jost Van } \\
\text { Dyke }\end{array}$ & 800 & 321 & - & + & + & - & - & + & 3 \\
\hline Mosquito & 50.5 & 83 & - & - & - & - & - & + & 1 \\
\hline Norman & 257 & 131 & + & + & - & - & - & - & 2 \\
\hline Tortola & 5,444 & 530 & - & + & + & - & - & + & 3 \\
\hline Virgin Gorda & 2,130 & 414 & - & - & + & - & - & + & 2 \\
\hline \multicolumn{10}{|c|}{ UNITED STATES VIRGIN ISLANDS } \\
\hline Grass Cay & 24 & 70 & - & + & - & - & - & - & 1 \\
\hline $\begin{array}{c}\text { Lovango } \\
\text { Cay }\end{array}$ & 45 & 75 & - & - & + & - & - & - & 1 \\
\hline St. Croix & 21,466 & 355 & + & + & + & + & - & + & 5 \\
\hline St. John & 5,180 & 387 & + & + & + & + & + & + & 6 \\
\hline St. Thomas & 7,660 & 470 & + & + & + & + & - & + & 5 \\
\hline Thatch Cay & 69 & 146 & - & + & - & - & - & - & 1 \\
\hline
\end{tabular}


Pallas's mastiff bats reported from that island. The bats from Mosquito Island were among nine individuals obtained from a colony of thirty to fifty bats occupying a coastal cliff fissure cave on 19 June 2007 by Jean-Pierre Bacle and Kevel Lindsay. The original sample was composed of two males and seven females of which two males and two females were preserved. The two bats from Jost Van Dyke were both females taken on the nights of 3 July and 14 October 2008. The conditions on Ridge Road on 3 July have been described in the account for A. jamaicensis. On 14 October a mist net was placed across Brown Ghut under a hog plum tree (Spondias mombin), which caught one M. molossus.

Forearm length and seven cranial measurements of these six specimens are presented in Table 1. We follow Koopman (1975) in using the subspecific epithet of M. m. fortis for all populations of this species occurring in the Virgin Islands except those on St. Croix, which he assigned to $M$. $m$. debilis. As we have indicated elsewhere this is a species that is in need of a modern systematic review.

Six of the seven females from Mosquito Island were pregnant and the seventh was post-lactating, but did not appear to be pregnant. The crown-rump lengths of the fetuses of two preserved females were 19 and 22. The female from Jost Van Dyke taken on 3 July carried an embryo, measuring 11 in crown-rump length, and the female obtained on 14 October was lactating. The lactating female weighed 13.9. A male from Mosquito Island (TTU 111443) was missing its upper left M3 and there was no evidence that the tooth had been present in life.

\section{Discussion}

The new records increase our knowledge of the distribution of bats on the British Virgin Islands within the Virgin Islands chiropteran complex. As can be seen in Table 2, the diversity of the chiropteran faunas of $U$. S. Virgin Islands still exceeds that for the British Virgin Islands. St. John, U. S. Virgin Islands, remains the only island within the Virgin Islands with a fauna of all six species of bats known from the islands. With the recent report of Stenoderma rufum by Kwiecinski and Coles (2007), St. Croix joins St. Thomas as islands from which five of the six species reported from Virgin Islands are known, with Tadarida brasiliensis missing from both islands. Tiny Guana Island with the addition of records of Noctilio leporinus and Tadarida brasiliensis becomes the third island with a fauna of five species and the first in the British Virgin Islands.

Lazell and Jarecki (1985) recorded only Artibeus jamaicensis and Molossus molossus based on voucher specimens and a sight record of Noctilio leporinus from Tortola. It is surprising that so few bat species are known from Tortola given that it is the largest of the British Virgin Islands (5,444 hectares) and the third largest of all of the islands in the complex (only St. Croix and St. Thomas are larger) and Tortola is the highest of all in elevation $(530 \mathrm{~m})$. The addition of Brachyphylla cavernarum to this fauna brings it more into line with diversity that might be expected on an island of this size.

Documentation of three species of bats on Jost Van Dyke increases the number of bats known from zero to three for this island. The addition of Noctilio leporinus to the bat fauna of the tiny island of Norman (257 hectares) brings its total to two species of bats. The need for additional field studies on the bat fauna of British Virgin Islands is emphasized by the currently known faunas from the islands of Virgin Gorda and Anegada. Virgin Gorda, the third largest of British Virgin Islands and the second highest, has a fauna of only two species. Anegada is a large island, but given its very low elevation and limestone nature it is not a diverse island. Nevertheless, a single species of bat occurring on the island seems low. Given our incomplete current data, it seems too early to examine the species/area relationships and other biogeographical parameters among these chiropteran faunas.

Acknowledgements.-We would like to thank the following curators and collection managers for making specimens in their collections available to us for study: Nancy B. Simmons and Darrin P. Lunde, American Museum of Natural History; Bruce D. Patterson and John D. Phelps, Jr., Field 
Museum of Natural History; Patricia W. Freeman and Thomas E. Labedz, University of Nebraska State Museum. We are particularly grateful to Angie Fox, Technical Artist, University of Nebraska State Museum, for creating Figure 1. We also thank the following individuals for their support: Bertrand Lettsome and Shannon Gore, Department of Conservation and Fisheries, British Virgin Islands Government; Clive Petrovic, Econcerns Ltd., British Virgin Islands; and Susan Zaluski and Rosemary DelaneySmith, Jost Van Dyke Preservation Society, British Virgin Islands.

\section{Literature Cited}

Allen, G. M. 1911. Mammals of the West Indies. Bull. Mus. Comp. Zool. 54:175-263.

Allen, J. A. 1890. Notes on a small collection of West Indian bats, with description of an apparently new species. Bull. Am. Mus. Nat. Hist. 3:169-173.

Anthony, H. E. 1925. Scientific Survey of Porto Rico and the Virgin Islands. Part I. Mammals of Porto Rico, living and extinct-Chiroptera and Insectivora. NY Acad. Sci. 9:1-96.

Bacle, J.-P., K. C. Lindsay, and G. G. Kwiecinski. 2008. Bats of St. Thomas and St. John, U. S. Virgin Islands: Priority conservation measures for species of greatest concern. Isl. Res. Found. Occ. Pap. 60:1-13.

Bond, R. M., and G. A. Seaman. 1958. Notes on a colony of Brachyphylla cavernarum. J. Mammal. 39:150-151.

Davis, W. B. 1973. Geographic variation in the fishing bat, Noctilio leporinus. J. Mammal. 54:862-874.

Genoways, H. H., S. C. Pedersen, P. A. Larsen, G. G. Kwiecinski, and J. J. Huebschman. 2008. Bats of Saint Martin, French West Indies/Sint Maarten, Netherlands Antilles. Mastozool. Neotrop. 14:169-188.
Genoways, H. H., R. M. Timm, R. J. Baker, C. J. Phillips, and D. A. Schlitter. 2001. Bats of he West Indian island of Dominica: Natural history, areography, and trophic structure. Spec. Publ., Mus. Texas Tech Univ. 43:1-43.

Goodwin, G. G. 1928. Observations on Noctilio. J. Mammal. 9:104-113.

Hall, E. R., and J. W. Bee. 1960. The red fig-eating bat Stenoderma rufum Demarest found alive in the West Indies. Mammalia 9:67-75.

Hall, E. R., and J. R. Tamsitt. 1968. A new subspecies of red fig-eating bat from Puerto Rico. Roy. Ont. Mus., Life Sci. Occ. Papers. 11:1-5.

Koopman, K. F. 1975. Bats of the Virgin Islands in relation to those of the Greater and Lesser Antilles. Am. Mus. Novit. 2581:1-7.

Kwiecinski, G. G., and W. C. Coles. 2007. Presence of Stenoderma rufum beyond the Puerto Rican bank. Occ. Papers Mus., Texas Tech Univ. 266:1-9.

La Bastille, A., and M. Richmond. 1973. Birds and mammals of Anegada Island, British Virgin Islands. Caribb. J. Sci. 13:91-109.

Lazell, J. D. 2005. Island: fact and theory in nature. Berkeley: Univ. Calif. Press.

Lazell, J. D., Jr., and L. Jarecki. 1985. Bats of Guana, British Virgin Islands. Am. Mus. Novit. 2819:1-7.

Schwartz, A. 1955. The status of the species of the brasiliensis group of the genus Tadarida. J. Mammal. 36:106-109.

Shamel, H. H. 1931. Notes on the American bats of the genus Tadarida. Proceed. U.S. Nat. Mus. 78:1-27.

Starrett, A. 1962. The bats of Puerto Rico and the Virgin Islands, with a check list and keys for identification. Caribb. J. Sci. 2:1-7.

Swanepoel, P., and H. H. Genoways. 1978. Revision of the Antillean bats of the genus Brachyphylla (Mammalia: Phyllostomatidae). Bull. Carnegie Mus. Nat. Hist. 12:1-53.

Swanepoel, P., and H. H. Genoways. 1983. Brachyphylla cavernarum. Mammal. Species 205:1-6.

Taboada, G. S. 1979. Los murciélagos de Cuba. Havana: Editoria de la Academia de Ciencias de Cuba. 